\title{
DURABILITY AND STRENGTH OF BOND BETWEEN MORTAR AND BRICK
}

\author{
By L. A. Palmer ${ }^{1}$ and J. V. Hall ${ }^{1}$
}

\section{ABSTRACT}

Durability and strength of bond between the mortar and brick of 1,296 brickmortar units have been studied. The materials used included five different makes of brick and two different mortars. Alternate freczing and thawing of moisture-saturated units 50 times followed by drying constituted the tests for bond durability. Strength of bond was determined after storace of other units for six months under three different conditions. Bond durability was increased 100 per cent by loading the units during weathering tests. The factors-pressure on the mortar joint, type of mortar used, degrce of wetting the brick, and apparent shrinkage of mortar-were of more importance relatively in their effect upon bond strength or durability than properties of the brick themselves.

\section{CONTENTS}

1. Purpose of the investigation

1. Purpose of the investigation_................. 474

2. Definition of terms. . .

II. Methods of test.

1. Total absorption

2. Classification of brick shipments................ 476

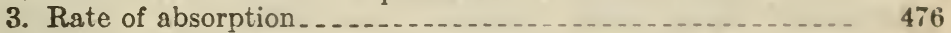

4. Preparation of specimens

5. Mortars used .

6. Preparation of units for test.

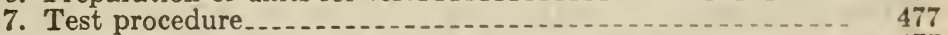

(a) Storage of units

(b) Tests for bond durability...... 479

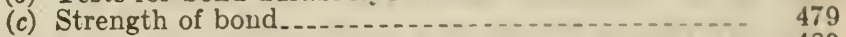

III. Results _ (c) Strength

1. Durability of bond... 481

(a) Durability of bond as affected by the degree of wetting different brick..................... 4 S2

(b) Bond durability as related to brick used.......... 483

(c) Effect of metal lugs in mortar.............. 483

(d) Durability of bond as related to absorption..... 484

(e) Effect of storage conditions ................... 4 45

(f) Durability of bond as related to mortar........ 485

(g) Effect of vertical loading .......... 486

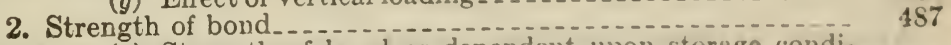

(a) Strength of bond as dependent upon storage condi- 487 tions $\ldots \ldots$.

(b) Strength of bond as related to brick

$\begin{array}{ll}\text { (c) Strength of bond versus absorption of brick-_..- } & 459 \\ \text { (d) Strength of bond as related to degree of wetting brick. } & 489\end{array}$

(e) Effect of metal lugs ........................ 490

(f) Strength of bond in units surviving freezing and 49

(g) Strength of bond as related to mortar.......... 491

IV. Conclusions
V. Acknowledgments

2 Research Associste for the American Face Brici Association. 


\section{INTRODUCTION}

\section{PURPOSE OF THE INVESTIGATION}

The marked degree of adhesion of mortar to brick is often noticed when old brick buildings are torn down. However, as was indicated in a previous publication, "Wet Walls and Efflorescence," where masonry is very freely exposed to adverse climatic conditions, cracks between mortar and masonry units are sometimes developed. That there are certain precautions which must be observed in matters relating to the design, construction, and maintenance of a building is a fact that was emphasized in that publication. The work herein outlined has been a continuation of this study.

That the mortar joints between masonry units may become disengaged from the units in undrained, horizontal exposures has been recognized. It is essential that the mechanism of the destruction of adhesion of mortar to brick, as well as to other masonry units, be better understood. That such failure is by no means confined to brickwork may be verified by field study. This fact is also illustrated by photographs in the publication mentioned above.

It is believed that too much stress has been placed, in the past, on the inherent strength of masonry materials while other properties may be of equal or even greater importance. It is conceivable that if the mortar and the unit undergo differential volume changes, then the two materials, unit and mortar, may become separated. This condition may lead to excessive water penetration. The purpose of this research was to find answers to such questions as the following:

Is "durability" of "bond" necessarily related to the "strength" of "bond" that may be developed?

All other things being constant, does either the "durability" or the "strength" of bond depend upon the type of brick used and if so, to what extent?

Does shrinkage of mortar tend to decrease the life of the "bond"?

Is the "bond" in a mortar joint that for the most part is not loadbearing, as "durable" as that in a load-bearing one?

Of two classes of masonry mortars that are bcing widely used, one a mixture of 1 volume of Portland cement to 3 volumes of sand, and the other a mixture of 1 volume of hydrated lime to 1 volume of Portland cement to 6 volumes of sand, would two such mortars exhibit a difference in "durability" of "bond"?

What effect has the degree of wetting brick (when laying them) upon either the "durability" or the "strength" of "bond"?

Is it good practice to always wot all brick when laying them in a wall?

Answers to these questions should point the way to improving the bond between mortar and brick. The field work ${ }^{3}$ had already indicated that the most vulnerable points in brickwork are between the brick and the mortar, and that generally the materials themselves are as weather resistant as may be desired.

\section{DEFINITION OF TERMS}

Bond.-The term "bond" as used herein, denotes a condition; that is, adhesion of mortar to brick.

2 Wet Walls and Eflorescence, publication of the American Face Brick Association, A. I. A. flle No. $5 \mathrm{~m}$.

Sce footnote 2, p. 
Durability.-The length of time that a mortar adheres to a brick is a measure of the "bond durability."

Strength.- "Strength of bond" is the degree of adherence of mortar to brick, expressed in terms of units of stress, such as pounds per square inch of bonded area.

Unit.-The term "unit" as used throughout this paper has reference to two bricks bonded together with mortar. A "loaded" unit is one to which a pressure, perpendicular to the plane of the mortar bed, is maintained throughout the tests for durability of bond.

Wetted.-The term "wetted" refers to a test procedure and is defined under Section II, 3.

\section{MATERIALS}

The lime used in the mortar conformed to the requirements of Federal Specifications Board specification No. 249 for masons' hydrated lime. The Portland cement met the requirements of Federal Specification for Portland cement as contained in Bureau of Standards Circular 33, fourth edition. Fairly clean Potomac River sand that had passed a No. 8 sieve was used. The screen analysis of this sand was as follows:

Through cent

Through No. 20, retained on No. 30 . 93.17

Through No. 30, re rained on No. 50

Through No. 50, retained on No. 100

Through No. $100 \ldots 8$

Total_...

Only marketable brick, made both from clay and from shale, were selected. A description of the five different manufacturers' brick used is as follows:

Brick No. 1.-Made from surface clay, molded dry-press; absorption range, 9.5 to 15.5 per cent; very high rate of absorption; specimens "wetted" from end to end within 30 minutes.

Brick No. 2.- Same as No. 1 except that absorption range was between the limits 11.5 to 17.0 per cent; very high rate of absorption; specimens tested "wetted" from end to end within one hour.

Brick No. 3.-Side-cut, stiff-mud brick, made from fire clay; absorption 4.8 to 9.8 per cent; very low rate of absorption; from four to six hours were required to "wet" specimens of this make from edge to edge.

Brick No. 4.- Side-cut, stiff-mud shale; absorption 5.2 to 10.7 per cent; very low rate of absorption; from 8 to 12 hours were required to "wet" through edge to edge, specimens of this make of brick.

Brick No. 5.- Side-cut, stiff-mud shale; absorption 6.0 to 11.5 per cent; very low rate of absorption; from four to six hours were required to "wet" specimens of this make of brick from edge to edge.

\section{METHODS OF TEST}

\section{TOTAL ABSORPTION}

Total absorption was determined by immersing brick for a period of 48 hours in water at normal room temperature, the dry weight having been previously determined by drying at $150^{\circ} \mathrm{C}$. to constant weight. The water absorbed was computed as percentage of the initial dry weight of the specimen. 


\section{CLASSIFICATION OF BRICK SHIPMENTS}

Each manufacturer's shipment of brick was divided into six groups. Each of these six groups represented a certain limited range in absorption. For example, the range of absorption for the six groups of brick No. 1 were: Group 1, 9.5 to 10.5 per cent, inclusive; Group $2,10.6$ to 11.5 per cent, inclusive; Group $3,11.6$ to 12.5 per cent inclusive; Group 4, 12.6 to 13.5 per cent, inclusive; Group 5, 13.6 to 14.5 per cent, inclusive; and, Group $6,14.6$ to 15.5 per cent, inclusive. Two brick of the same group (never from different groups) were bonded together with mortar.

\section{RATE OF ABSORPTION}

The rate of absorption was determined in the following manner. Brick were stood either on end or on edge in about 1 inch of water and the time taken for water to rise by capillarity to the upper surface was observed and recorded. The number so tested was 60 for each manufacturer's shipment. When the rate of absorption was such that more than one hour was required to wet the specimens from end to end, these tests were conducted in a humid chamber to prevent excessive evaporation from the surfaces.

\section{PREPARATION OF SPECIMENS}

Bricks were set under three conditions, namely, dry, 50 per cent saturated and 80 per cent saturated. The gain in weight equivalent to the desired degree of saturation was computed from the known amount of total water absorption as previously determined. The specimens were immersed in water, and removed and weighed periodically, until the predetermined gain in weight was reached.

\section{MORTARS USED}

Two mortars were used One of these was the rather widely used $1: 1: 6$ mortar, the numbers referring to proportions by volume of lime, Portland cement and sand, respectively. The other contained only Portland cement and sand in the ratio, $1: 3$ by volume. The amount of mixing water was 16.2 per cent of the total weight of water, lime, cement, and sand in the $1: 1: 6 \mathrm{mix}$ and 15.2 per cent of the weight of water, cement, and sand in the $1: 3$ mortar. The five types of brick were used with one mortar $(1: 1: 6)$ in the study of bond durability and strength as related to different makes of brick. One type of brick (No. 5) was used in the study of strength and durability of bond obtained with two different mortars; that is, the mixes, $1: 1: 6$ and $1: 3$.

\section{PREPARATION OF UNITS FOR TEST}

The mortar joints at the time of forming the units were three-eighths inch in thickness. Brass lugs, three-eighths inch in height, were embedded in the mortar joint of one-half of all of the units. Each lug was covered by a thin layer of mortar so that metal and brick would not be in intimate contact and a more even bearing surface could be secured. Three lugs were embedded in a joint, two near one end of the horizontal joint (all brick being laid together flatwise) and about $2 \frac{1 / 2}{2}$ inches apart and a third at the other end and opposite the mid point on a line joining the first two lugs. In units made without lugs it was 
somewhat more difficult to obtain joints of uniform thickness. However, with care and practice, the variation in thickness of joints even in these cases was kept within reasonable limits.

In order that the mortar might not be allowed to remain too long before use, one batch sufficient in quantity to bond together six units was made at a time. Joints were made flush and immediately upon placing the upper brick on the layer of mortar on the brick beneath, the operator's full weight was applied to the top brick for about one minute so as to produce intimate contact between mortar and brick.

This latter procedure was modified when it was desired to study the effect of maintaining a pressure perpendicular to the bed of mortar throughout the whole period of testing. In this case a band of drilled strap iron (holes at half-inch intervals) was fitted about the middle of the unit and a machine bolt, $1 / 4$ by 2 inches (20 threads per inch), was placed through the overlapping holes. The threaded end rested in a depression in an iron plate lying at the center of the upper surface of the top brick, a nut on the bolt being beneath the overlapping bands. The unit was thus strapped at the time of forming it and an indefinite load was applied by turning the bolt with a 6 -inch lever. Forty-eight hours after forming the unit, the band was made as tight as possible by applying a force of about 150 pounds at the end of the 6 -inch lever arm. When the same procedure was followed, using a proving ring instead of a unit, it was found that the total pressure obtained varied from 500 to 800 pounds. Due to some degree of plastic flow and to shrinkages and expansions in the mortar during the process of testing, this load could not, of course, remain constant. It was observed that the bolts generally remained very tight, this condition being checked at the end of a definite period of storage of the units and prior to freezing and thawing tests. Although the load on these units was not constant, it was considered that it was at least as great at all times as that on masonry units in walls typical of modern methods of construction.

\section{TEST PROCEDURE}

\section{(a) STORAGE OF UNITS}

All units remained in the laboratory during the first 48 hours. The temperature range in the laboratory was from $15^{\circ}$ to $32^{\circ} \mathrm{C}$, , the average being about $20^{\circ} \mathrm{C}$. The relative humidity varied from 20 to 80 per cent, but usually was within the limits, 30 to 50 per cent.

The procedure followed with bricks Nos. 1 to 4 , inclusive, using the $1: 1: 6$ mortar only, and brick No. 5 using both the $1: 3$ and the $1: 1: 6$ mortars, is given in Table 1 . The six units in the smallest subdivision of units (Table 1) represented the six groups of each shipment as based on percentage absorption. Thus each group of each shipment of brick was represented in every one of the final subdivisions of six units. After remaining for 48 hours in the laboratory, equal numbers of the units were stored under the following conditions: In the laboratory, out of doors, and in a room wherein the relative humidity was fairly constant (approximately 95 per cent) and the temperature was $70^{\circ} \mathrm{F}$. Units which underwent durability tests remained in storage for two months prior to such tests. Units which did not undergo durability tests remained in storage for six months, at the end of which time the strength of bond was determined. 


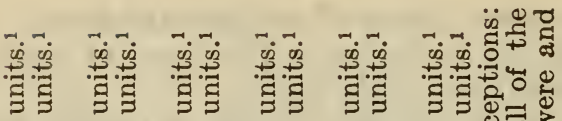

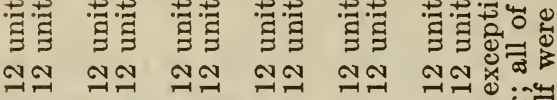

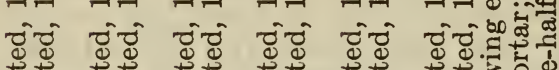

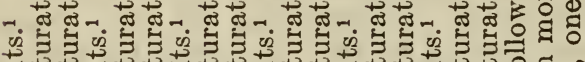

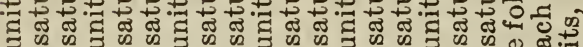

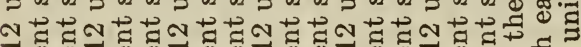

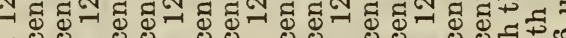
no

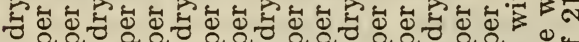

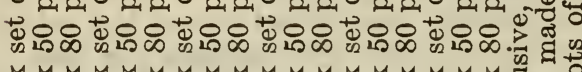

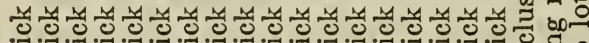
ติ.

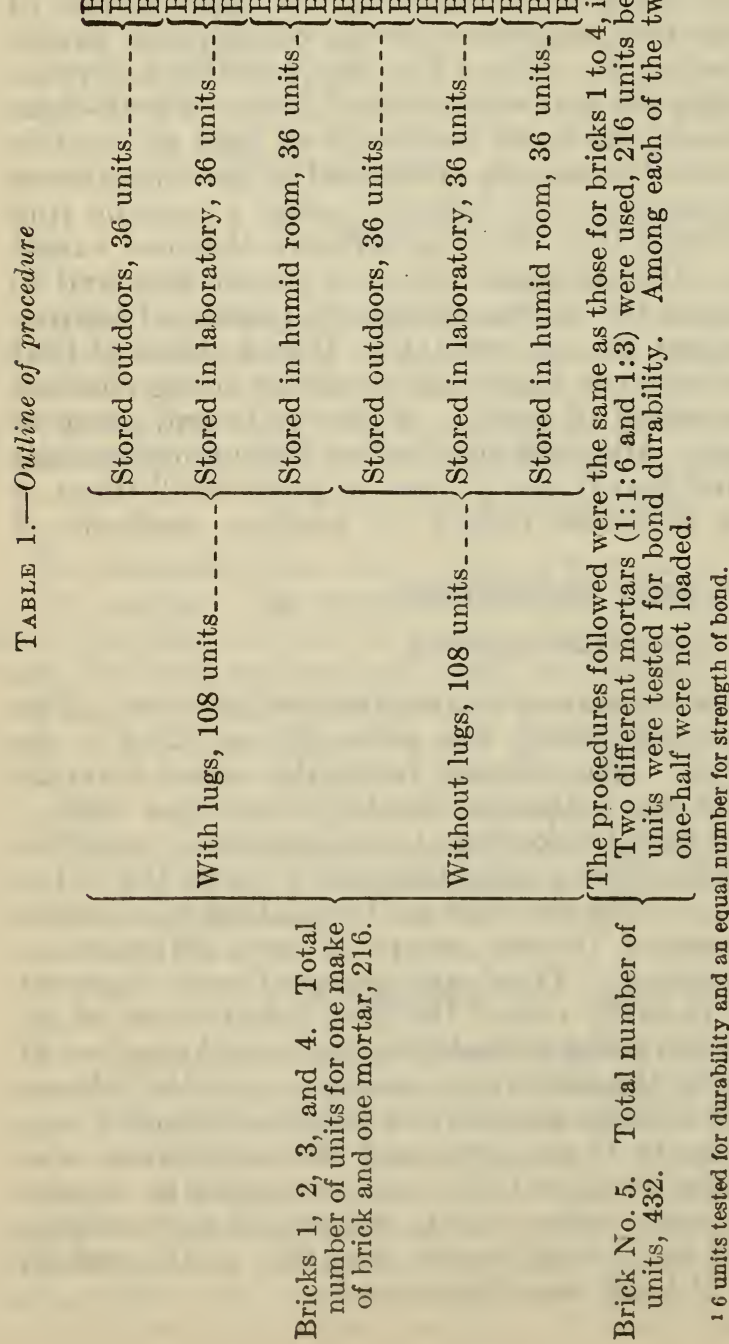




\section{(b) TESTS FOR BOND DURABILITY}

After storage for two months those units undergoing durability tests were removed, immersed for 48 hours in water, then placed in pans containing a half-inch of water (flat side of bottom brick of unit down) and conveyed to a freezing chamber where they remained for about 18 hours. They were then thawed by immersion in water maintained at about normal room temperature. One freezing followed by one thawing constituted a cycle. There were 50 such cycles. Following each thawing, the units were examined and any bond failures were noted. It was considered that the bond had failed, when on picking up the unit by the top brick, the lower one became separated from it.

Following the 50 cycles of freezing and thawing, the "survivors" among all units so tested were dried for three weeks on the upper shelf of a large gas oven at a temperature ranging from $80^{\circ}$ to $100^{\circ} \mathrm{F}$. During this drying procedure the bond failed in many instances. It was, of course, impossible to assign any definite share of such failure to the drying operation alone, the bond having been most likely weakened previously in the weathering tests. In every instance, units which survived the bond durability tests were reserved for tests for strength of bond.

\section{(c) STRENGTH OF BOND}

The half of all of the units made and which remained in storage for a period of six months were removed after this period of time and, together with those units which survived the durability tests, were dried for three weeks. After drying, the units were coated with plaster of Paris, the plaster being applied over the edges of the brick and mortar. The unit lying on its side was pressed down into a sufficient quantity of plaster of Paris paste of proper consistency spread on a glass plate. A similar quantity of the paste was then applied on the upper surface of the unit as it rested in the lower plaster bed. By means of accurately machined spacers between the bottom glass plate and an upper one pressed down on the top bed of plaster, parallelism of the two opposite plastered surfaces was assured. The excess plaster was trimmed away from the edges and, after setting, the plates could be easily removed without cracking the plaster. The thickness of the plaster coat on the two opposite longitudinal faces of the unit was about one-sixteenth to oneeighth inch. After hardening, the plaster covering the mortar joint was carefully removed by means of a hacksaw and a steel spatula.

The device for gripping the unit in testing for strength of bond was a slight modification of that described by McBurney ${ }^{4}$ in his study of the strength of brick in tension. This device is illustrated by Figures 1 and 2. Steel shims of different degrees of thickness could be inserted between the wedges, $W$, and the steel faces, $F$, and allowed for variations in thicknesses of the plastered brick. The downward pull on the lower block gripping the lower brick was applied slowly. With the machine in low gear this downward movement of the head was 0.01 of an inch per minute. Actually, the travel of the block was less, due to the slow taking up of slack in the 
gripping device. $S$ and $S^{\prime}$ (fig. 2) represent concentric steel surfaces separated by 14-inch steel balls. The radius of curvature of the outer spherical surface was 6.9 inches in each case, bringing the center of curvature within the center of the mortar joint, $M$. To keep the lower block from falling back on the head of the machine when the units were pulled apart, heavy metal "safety straps" were bent and suspended from the upper block so as to catch the lower one when it fell.

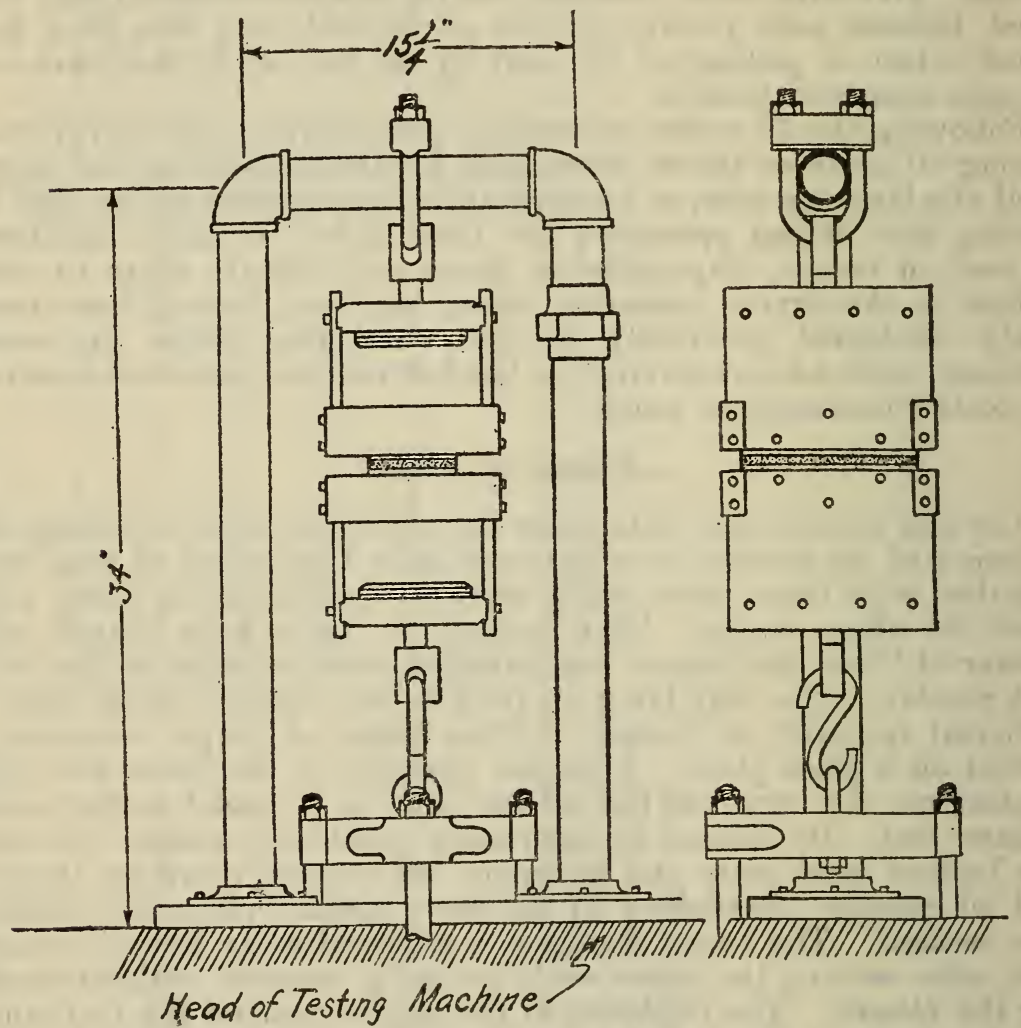

Figure 1.-Assembled apparatus used in tesing units in tension

In computing the data relative to tests for strength of bond the total load was divided by the total area of the mortar bed, the dimensions of the latter being measured by a rule marked in tenths of an inch. Unbonded areas were not deducted in any case from the total area.

\section{RESULTS}

Brick Nos. 1 and 2 absorbed water far more rapidly than Nos. 3 , 4 , and 5 , and it soon became evident that failure to have specimens of the former at least 80 per cent saturated at the time of laying them, constituted poor workmanship. However, this type of poor workmanship was one of the variable factors to be studied. Specimens of brick Nos. 1 and 2 when not wetted sufficiently, dried the wet 
mortar very quickly when it was applied, thereby making it difficult to obtain a good mechanical bond initially. This apparently was not the case with brick Nos. 3,4 , and 5 . It will be shown later (Pt. III, sec. 2) that failure to have specimens of brick Nos. 1 and 2 sufficiently saturated when laying them resulted in "patches" of unbonded areas. Apparently, wetting specimens of brick Nos. 3, 4, and 5 did not interfere with the development of a good mechanical bond, but would seem to be an unnecessary operation and might detract from the neatness of construction.

For these reasons, only those results for durability and strength tests obtained with the units made from brick Nos. 1 and 2 in which

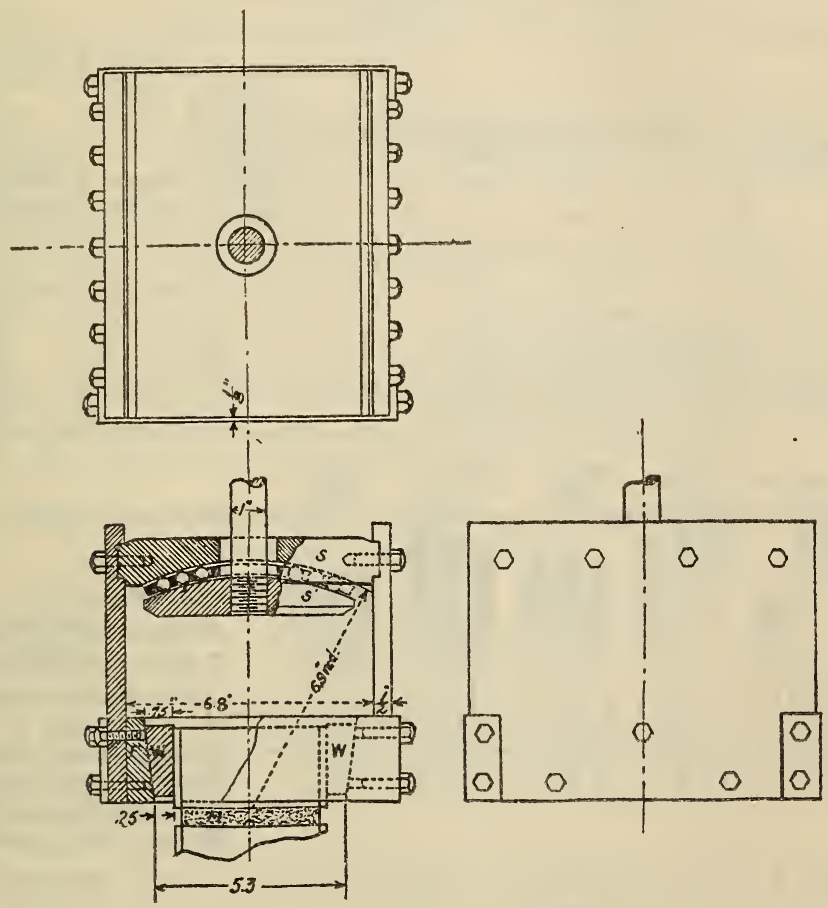

FIGURE 2.-Details of spherical bearing and grips for apparatus

the specimens were 80 per cent saturated when set, are considered in the averages, except in those instances wherein the degree of saturation of the brick is the particular variable considered.

\section{DURABILITY OF BOND}

It must be realized that this test was very severe. For comparative data the results should be indicative of the importance of various factors involved in the durability of bond. It must not be considered that the large number of failures of bond is indicative of any glaring defect in brickwork. It is not possible to duplicate in every respect, in laboratory tests, conditions obtaining in a wall and to complete such tests during any reasonable length of time. Con- 
sequently the results may often be misleading if this fact is not appreciated and thoroughly borne in mind.

The average percentage failures of bond during the tests are given in the following tabulations of results.

\section{(a) DURABILITY OF BOND AS AFFECTED BY THE DEGREE OF WETTING}

Consider first the durability of bond as affected by the degree of wetting the different brick at the time of forming the units. This is illustrated by the data in Table 2 .

TABLE 2.-Effect of wetting brick

\begin{tabular}{|c|c|c|c|c|c|c|}
\hline \multirow{2}{*}{ Brick } & \multirow{2}{*}{$\begin{array}{l}\text { Total ab- } \\
\text { sorption } \\
\text { (range) }\end{array}$} & \multirow{2}{*}{$\begin{array}{l}\text { Rate of absorption (time in hours to } \\
\text { wet through) }\end{array}$} & \multirow{2}{*}{$\begin{array}{l}\text { Number } \\
\text { of test } \\
\text { units } \\
\text { averaged } \\
\text { for each } \\
\text { condi- } \\
\text { tion of } \\
\text { wetting }\end{array}$} & \multicolumn{3}{|c|}{$\begin{array}{l}\text { Failure of bond (1: } 1: 6 \text { mor- } \\
\text { tar, units with and without } \\
\text { lugs) }\end{array}$} \\
\hline & & & & $\begin{array}{l}\text { Brick } \\
\text { set dry }\end{array}$ & $\begin{array}{l}\text { Brick } 50 \\
\text { per cent } \\
\text { saturated } \\
\text { when set }\end{array}$ & $\begin{array}{l}\text { Brick } 80 \\
\text { per cent } \\
\text { saturated } \\
\text { when set }\end{array}$ \\
\hline $\begin{array}{l}\text { No. } 1 \\
\text { No. } 2 \\
\text { No. } 3 \\
\text { No. } 4 \\
\text { No. } 5 \\
\end{array}$ & $\begin{array}{c}\text { Per cent } \\
9.5-15.5 \\
11.5-17.5 \\
4.8-9.8 \\
5.2-10.7 \\
6.0-11.5\end{array}$ & $\begin{array}{l}1 / 4 \text { to } 1 / 2 \text { hour (end to end) } \\
3 / 4 \text { to } 1 \text { hour (end to end) } \\
4 \text { to } 6 \text { hours (edge to edge) } \\
6 \text { to } 12 \text { hours (edge to edge) } \\
4 \text { to } 6 \text { hours (edge to edge) }\end{array}$ & $\begin{array}{l}36 \\
36 \\
36 \\
36 \\
36\end{array}$ & $\begin{array}{r}\text { Per cent } \\
97 \\
100 \\
78 \\
89 \\
75\end{array}$ & $\begin{array}{r}\text { Per cent } \\
97 \\
94 \\
86 \\
89 \\
77\end{array}$ & $\begin{array}{r}\text { Per cent } \\
67 \\
92 \\
81 \\
97 \\
83\end{array}$ \\
\hline
\end{tabular}

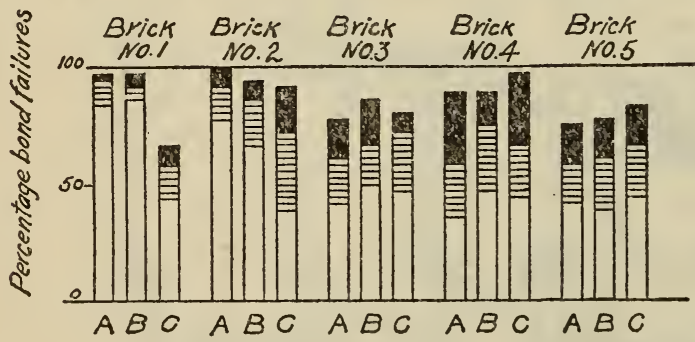

\section{Legend}

A.Brick set dry

B. Brick set $50 \%$ saturated

C. Brick set $80 \%$ osaturated

$\Pi$ Bond failures during first

$\checkmark$ ten cycies

目Bondfoilures betweententh 貝and Iwenty firth cycle

Bondfailures during last

A twenty five cycles

FigURE 3.-Bond durability as related to degree of wetting different brick

Figure 3 shows the approximate rates of bond failures (given in Table 2) during the first 10, between the tenth and twenty-fifth, and between the twenty-fifth and fiftieth freezing and thawing cycles. It is evident that wetting specimens of bricks Nos. 1 and 2 tended to markedly reduce the percentage failures of bond during the first 10 cycles. However, from Figure 3 it is apparent that this was not so in the case of units made with brick Nos. 3,4 , and 5 . It is seen that the distributions of percentage bond failures for units with these brick over the intervals considered are much more uniform for the three conditions of wetting than obtains in the case of brick Nos. 1 and 2 . It is noted, however, that the greatest number of bond failures per cycle occurred during the first 10 cycles in all cases.

From Table 2 it is clearly evident that marked improvement in bond durability in units made with brick No. 1 was effected by having specimens of this brick 80 per cent saturated when set. It is not so 
evident from Table 2 that this was so in the case of brick No. 2. As noted above, however, the number of bond failures during the first 10 cycles was markedly decreased by having specimens of this brick 80 per cent saturated. It might be also concluded that neither harm nor good resulted from wetting specimens of brick Nos. 3 and 5 . The data indicate that there was some slight improvement in bond durability with units containing brick No. 4 by having specimens of this brick completely dry when forming the units.

The effect of wetting or not wetting specimens of brick Nos. 1 and 2 is further illustrated by the data of Table 12 where strength of bond is considered.

Specimens of brick No. 2 contained from 12 to 15 per cent lime, particles of such being clearly visible. It is believed that hydration of this uncombined lime caused an expansion of the specimens. Brick Nos. 1 and 2 had very similar properties aside from their free lime contents (specimens of brick No. 1 containing no lime particles) and it is likely that the percentage bond failures with brick No. 2 was higher than that for brick No. 1 for this reason. Some of the specimens of brick No. 2 when tested individually (not in units) began to disintegrate after 80 freezing and thawing cycles.

(b) BOND DURABILITY AS RELATED TO GRICK USED

The data of Table 2 are rearranged to indicate the variation in durability of bond which may be expected when dissimilar brick are used with one mortar. These data appear in Table 3.

TABLE 3.-Variation of bond durability with respect to brick used (1:1:6 mortar, units with and without lugs)

\begin{tabular}{|c|c|c|}
\hline Brick & $\begin{array}{l}\text { Number } \\
\text { of units } \\
\text { averaged }\end{array}$ & Percentage failures during tesis \\
\hline $\begin{array}{l}\text { No. } 1 \\
\text { No. } 2 \\
\text { No. } 3 \\
\text { No. } 4 \\
\text { No. } 5 \\
\end{array}$ & $\begin{array}{r}36 \\
36 \\
108 \\
108 \\
108\end{array}$ & $\left.\begin{array}{l}67 \\
92 \\
82 \\
92 \\
92 \\
79\end{array}\right\}$ A verage for rough, relatively impervious brick, 84 per cent. \\
\hline
\end{tabular}

There have been numerous opinions expressed to the effect that a relatively dense and impervious brick will not bond with mortar. The data of Table 3 indicate that such is not the case, but that brick may vary quite widely in absorption properties without affecting materially the life of the bond. In fact the average of failures for brick No. 4 , representative of the densest material, is no greater than that of No. 2, the most porous material considdered here.

(c) EFFECT OF METAL LUGS IN MORTAR

It is interesting to note the effect of the presence of the lugs embedded in the mortar on the durability of bond. This is shown by the data in Table 4. 
TABLE 4.-Effect of lugs on bond durability $(1: 1: 6$ mortar $)$

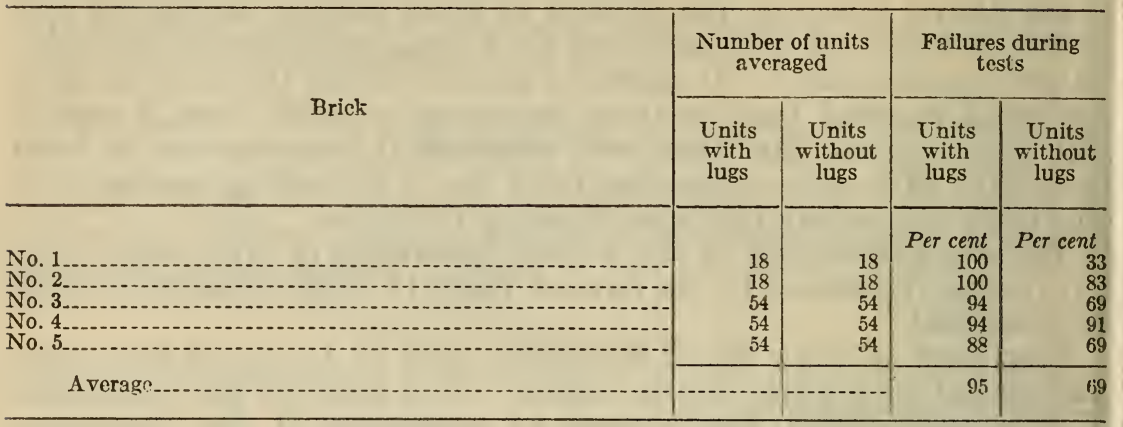

With five different types of brick bonded together with one $(1: 1: 6)$ mortar, the units in each of the five cases having been stored under identical conditions and all other conditions of test being the same, the durability of bond was less, without a single exception, when lugs were embedded in the joint. This indicates that shrinkage of mortar during the period of storage may have weakened the bond between the brick and mortar because the brick were not free to move toward one another and may have been torn loose in places from the cementing material. The grand average for the five different makes of brick under the conditions of testing is 95 per cent failures with, and 69 per cent failures without, lugs. This may in part explain the observation that cracks are more apt to occur in vertical than in horizontal joints, since it is obvious that brick are usually not free to move horizontally toward each other.

\section{(d) DURABILITY OF BOND AS RELATED TO ABSORPTION}

As stated above, each manufacturer's brick shipment was divided into six groups, each group containing specimens of very nearly the same absorption. Any relation existing between absorption and bond durability is further emphasized by considering the group averages within each shipment of brick. The resulting averages are given in Table 5.

TABLE 5.-Durability of bond versus degree of absorption of brick (1:1:6 mortar, with and without lugs)

\begin{tabular}{|c|c|c|c|c|c|c|}
\hline \multirow{2}{*}{ Brick } & \multicolumn{3}{|c|}{$\begin{array}{l}\text { Units formed with brick of } \\
\text { groups } 1 \text { to } 3 \text {, inclusive, lower } \\
\text { range of absorption }\end{array}$} & \multicolumn{3}{|c|}{$\begin{array}{l}\text { Units formed with brick of } \\
\text { groups } 4 \text { to } 6 \text {, inclusive, higher } \\
\text { range of absorption }\end{array}$} \\
\hline & $\begin{array}{c}\text { Absorption } \\
\text { range }\end{array}$ & $\begin{array}{c}\text { Bond } \\
\text { failures }\end{array}$ & $\begin{array}{l}\text { Number } \\
\text { averaged }\end{array}$ & $\begin{array}{c}\text { Absorption } \\
\text { range }\end{array}$ & $\begin{array}{l}\text { Bond } \\
\text { failures }\end{array}$ & $\begin{array}{l}\text { Number } \\
\text { averaged }\end{array}$ \\
\hline $\begin{array}{l}\text { No. } 1 \ldots \\
\text { No. } 2 . \\
\text { No. } 3 . \\
\text { No. } 4 \\
\text { No. } 5\end{array}$ & $\begin{array}{r}\text { Per cent } \\
9.5-12.5 \\
11.5-14.5 \\
4.8-7.0 \\
5.2-8.0 \\
6.0-9.0\end{array}$ & $\begin{array}{r}\text { Per cent } \\
68 \\
94 \\
89 \\
94 \\
86\end{array}$ & $\begin{array}{l}18 \\
18 \\
54 \\
54 \\
54\end{array}$ & $\begin{array}{r}\text { Per cent } \\
12.5-15.5 \\
14.5-17.5 \\
7.0-9.8 \\
8.0-10.7 \\
9.0-11.5\end{array}$ & $\begin{array}{r}\text { Per cent } \\
68 \\
90 \\
74 \\
91 \\
71\end{array}$ & $\begin{array}{l}18 \\
18 \\
54 \\
54 \\
54\end{array}$ \\
\hline Average. & & 86 & & & 79 & \\
\hline
\end{tabular}


The differences in this instance are not significant. With the possible exception of units made with brick Nos. 3 and 5, it is apparent that the durability of bond is not materially affected by variations in the degree of absorption within the limits characteristic of a single shipment.

\section{(e) EFFECT OF STORAGE CONDITIONS}

During the two months period of storage prior to freezing and thawing tests it was apparent (Pt. III, sec. 2) that the mortar in units stored out of doors or in the humid room developed a greater strength than that attained in mortar within units stored for the same length of time in dry storage, that is, in the laboratory. It would seem, therefore, that if durability were dependent upon strength, there would be a relatively greater percentage of bond failures among units which had remained in dry storage. In Table 6 the effect of storage on bond durability may be noted.

TABLE 6.-Effect of storage on bond failure during subsequent durability tests (1:1:6 mortar, with and without lugs)

\begin{tabular}{|c|c|c|c|c|c|c|}
\hline \multirow[b]{2}{*}{ Brick } & \multicolumn{3}{|c|}{ Number averaged } & \multicolumn{3}{|c|}{ Failures } \\
\hline & $\begin{array}{l}\text { Outdoor } \\
\text { storage }\end{array}$ & $\begin{array}{l}\text { Labora- } \\
\text { tory } \\
\text { storage }\end{array}$ & $\begin{array}{l}\text { Humid } \\
\text { room } \\
\text { storage }\end{array}$ & $\begin{array}{l}\text { Outdoor } \\
\text { storage }\end{array}$ & $\begin{array}{l}\text { Labora- } \\
\text { tory } \\
\text { storage }\end{array}$ & $\begin{array}{l}\text { Humid } \\
\text { room } \\
\text { storage }\end{array}$ \\
\hline $\begin{array}{l}\text { No. } 1 \\
\text { No. } 2 \\
\text { No. } 3 \\
\text { No. } 4 \\
\text { No. } 5\end{array}$ & $\begin{array}{l}12 \\
12 \\
36 \\
36 \\
72\end{array}$ & $\begin{array}{l}12 \\
12 \\
36 \\
36 \\
72\end{array}$ & $\begin{array}{l}12 \\
12 \\
36 \\
36 \\
72\end{array}$ & $\begin{array}{r}\text { Per cent } \\
69 \\
92 \\
86 \\
83 \\
73\end{array}$ & $\begin{array}{r}\text { Per cent } \\
50 \\
83 \\
92 \\
100 \\
75\end{array}$ & $\begin{array}{r}\text { Per cent } \\
83 \\
100 \\
67 \\
95 \\
88\end{array}$ \\
\hline Average.. & & & & 81 & 80 & 87 \\
\hline
\end{tabular}

Certainly the bond in those units in which the mortar had developed relatively greater strength (Table 9, Pt. III, sec. 2) was no more durable than it was in units wherein the mortar had not become so strong. A consideration of the combined data of the two tables (Nos. 6 and 9) justifies the belief that strength was of no great importance in so far as the durability of the bond in the units was concerned.

(f) DURABILITY OF BOND AS RELATED TO MORTAR

One make of brick, No. 5, was used in the study of comparative durability of bond with two different mortars. The results are given in Table 7.

TABLE 7.-Durability of bond as related to mortar used (units loaded and not loaded, with and without lugs)

\begin{tabular}{|r|r}
$\begin{array}{c}\text { Failures } \\
\text { during } \\
\text { tests }\end{array}$ & $\begin{array}{r}\text { Number } \\
\text { averaged }\end{array}$ \\
\hline Per cent & \\
48 & 216 \\
61 & 216
\end{tabular}


It may be mentioned in this connection that in preliminary work by the authors, the dregee of expansion on wetting, and contraction on drying, of this 1:1:6 mortar was found to be somewhat greater than similar volume changes of this $1: 3$ mortar. This has also been observed by Davis. ${ }^{5} \quad$ These changes occurred subsequent to hardening, and under conditions identical in the two cases. It is hoped that much more information relative to volume changes in mortar may be available for a future publication, and too much importance should not be attached to these data of Table 7 at the present time. It may be mentioned that since these tests were made, 1:1:6 mortar mixtures have been found which exhibit volume changes less in magnitude than those characteristic of the straight cement mortar.

\section{(g) EFFECT OF VERTICAL LOADING}

One manufacturer's brick (No. 5) was used to study the effect of loading. Comparative durability values are given in Table 8 , and include averages for units loaded and not loaded during testing. This includes equal numbers of units made with $1: 3$ and $1: 1: 6$ mortar.

TABLE 8.-Durability of bond as increased by a vertical load on bondea' units (with $1: 1: 6$ and $1: 3$ mortar, with and without lugs)

Units not loaded.

Units loaded.

\begin{tabular}{|r|r}
$\begin{array}{c}\text { Failures } \\
\text { of bond } \\
\text { during } \\
\text { tests }\end{array}$ & $\begin{array}{r}\text { Number } \\
\text { averaged }\end{array}$ \\
\hline Per cent & \\
73 & 216 \\
36 & 216
\end{tabular}

The averages apply to results obtained from testing 216 units not loaded and an equal number loaded, and should, therefore, be representative. The bond durability was doubled by imposing a pressure perpendicular to the mortar bed. There may be various reasons for this. A continuous pressure so applied may tend to restrain to some extent the forces produced by differential volume changes between brick and mortar. Again, it may insure much more intimate contact between the brick and cementing material. This is probably another reason for the occurrence of cracks between brick and mortar in vertical joints which are, for the most part, nonload bearing.

Figure 4 is an illustration of a typical failure of a nonloaded and Figure 5 is similarly one of a loaded unit during the freezing and thawing tests. Note that there was about equal adherence of mortar to each individual brick in the latter case. (Fig. 5.) As illustrated in Figure 4, the top brick of nonloaded units usually had considerably less mortar adhering to them than the lower brick after failure. Figure 6 illustrates a somewhat unusual case in the progressive failure of bond. Here the mortar sheared loose in part both from the upper and from the lower brick.

That the bond failure was not due to disintegration of either the brick or mortar is indicated by the following facts. When the

${ }^{5}$ Raymond F. Davis and G. W. Troxell, Volumetric Changes in Portland Cement Mortars and concretes, Proc. Am. Concrete Inst., 25, pp. 210-260; 1929. 
B. S. Journal of Research, RP290

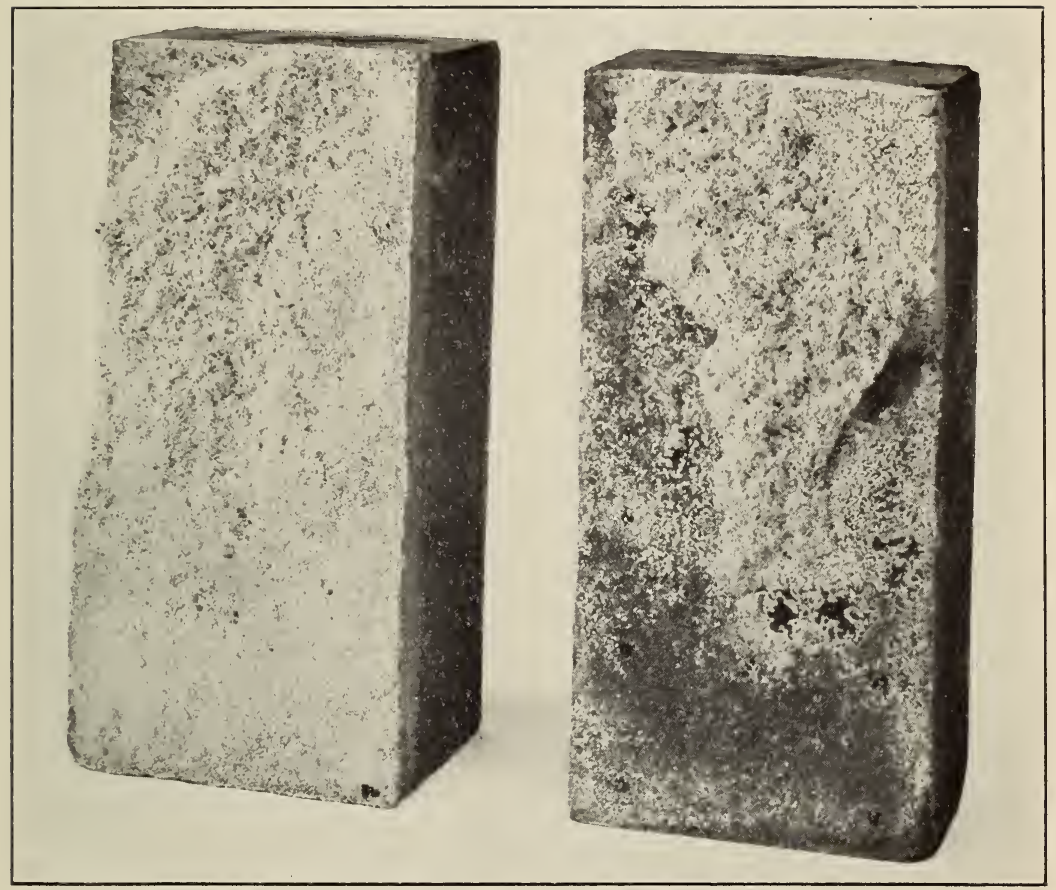

FIgure 4.-Typical bond failure in a nonloaded unit 
B. S. Journal of Research, RP290

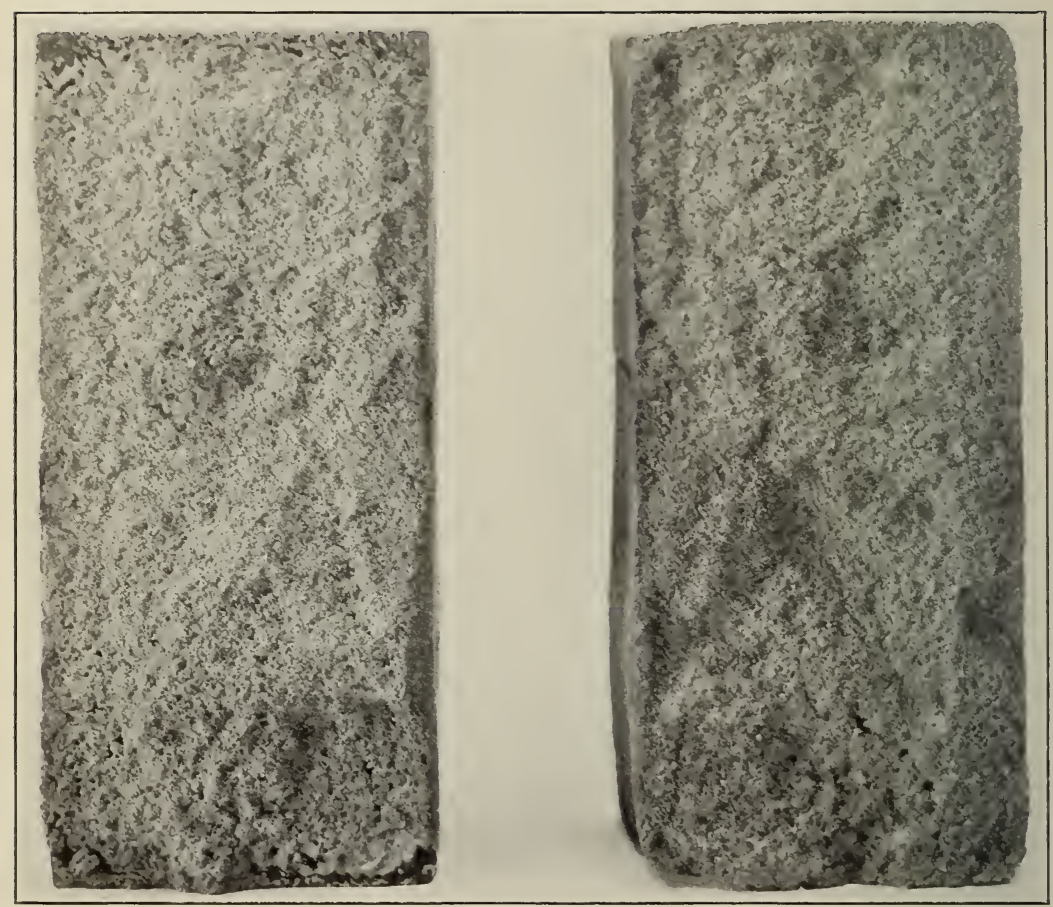

Figure 5.-Typical bond failure in a loaded unit 


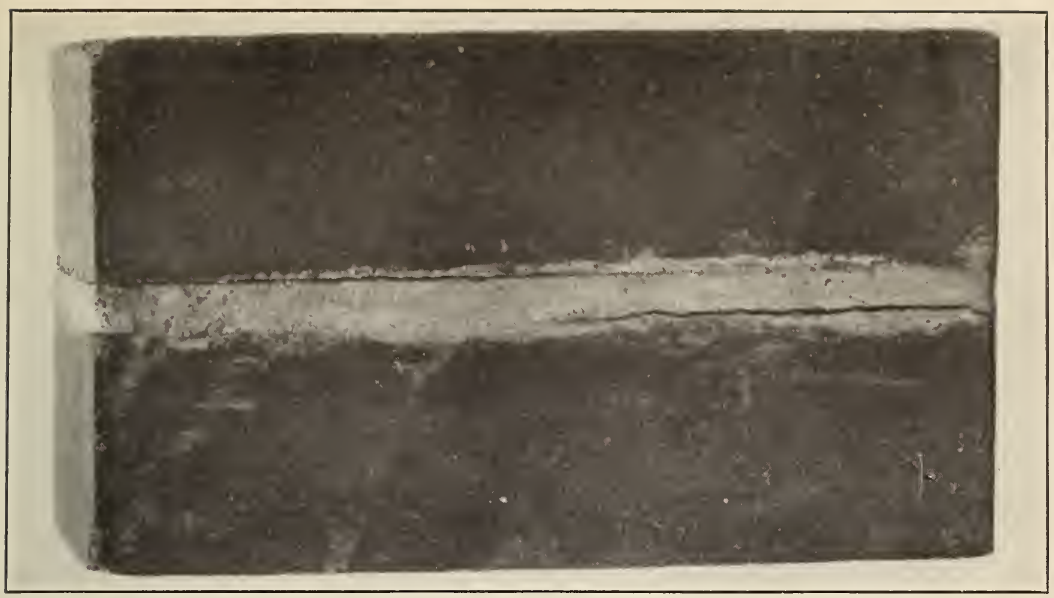

Figure 6.-An unusual case of bond failure

The mortar, initially well bonded, sheared loose from both brick in the unit during freezing and thawing.

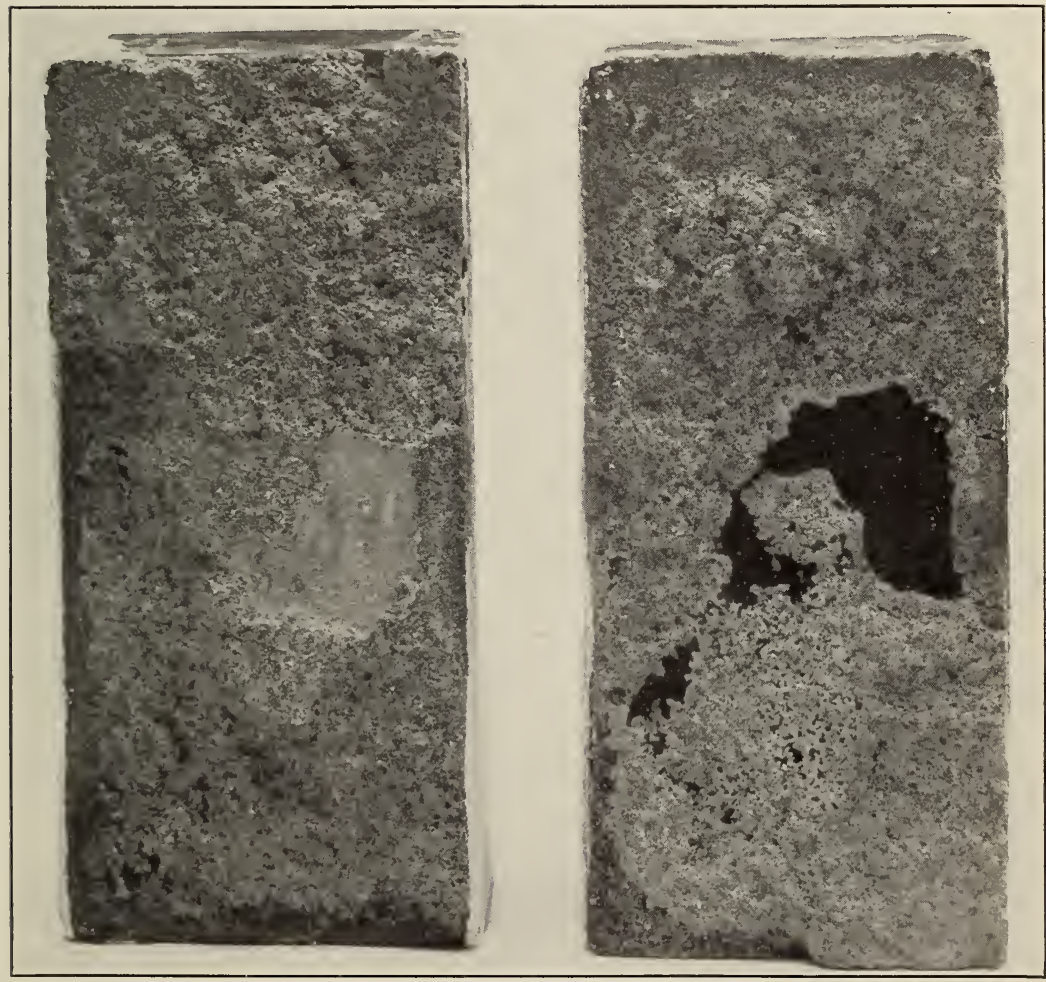

FIGURE 7.-Effect of not saturating sufficiently a rapidly absorbing brick when laying it in mortar

Note the unbonded areas. 
strength of bond was determined for units which had survived the freezing and thawing tests, it was found that the degree of adhesion of mortar to brick compared favorably with that obtaining in units formed with the same brick and mortar but which had remained in storage and had not been subjected to freezing and thawing. Moreover, after any failure of bond, the mortar was firm in all cases and not "crumbly." As the photographs (figs. 4, 5, and 6) show, failure apparently was due to stresses between brick and mortar, and it is suggested that this condition may, in part, have been caused by unequal volume changes in the two materials. This will be considered in another report to be published later, and dealing exclusively with volume changes in these materials. It may be stated here, however, that the expansion of these brick on prolonged wetting was relatively small in all cases as compared to the expansion produced by wetting these same mortars used in forming these units.

\section{STRENGTH OF BOND}

In the study of strength of bond it was proposed to find the relative importance of various factors, such as climatic conditions, the degree of absorption and the roughness of surface of brick, the extent to which a brick is wetted when it is laid up with mortar, and the degree of shrinkage which the mortar may undergo. Each of these is more or less important in determining the development of strength, both in the mortar as a material and in its degree of adhesion to the bonded unit. The units stored outdoors were exposed for the most part to winter conditions. It was impossible to make them all on the same day, but the comparative results as given below refer to units that were taken to their respective storage places within the same two months. This introduced normal variations in conditions of outdoor storage, but the variations in laboratory and humid room storage conditions were relatively small.

\section{(a) STRENGTH OF BOND AS DEPENDENT UPON STORAGE CONDITIONS}

In Table 9 are given comparative data showing the effects of storage on strength of bond at the end of six months. The procedure followed in computing the data in Tables 9,10 , and 11 with respect to brick Nos. 1 and 2 was the same as that followed in preparing Tables 3 to 6 , inclusive; that is, only data for those units made with brick Nos. 1 and 2 which were 80 per cent saturated were averaged.

TABLE 9.-Effect of storage conditions ( 6 months) on strength of bond (1:1:6 mortar, with and without lugs)

\begin{tabular}{|c|c|c|c|c|c|c|}
\hline \multirow[b]{2}{*}{ Brick } & \multicolumn{3}{|c|}{ Number averaged } & \multicolumn{3}{|c|}{ Average } \\
\hline & $\begin{array}{l}\text { Outdoor } \\
\text { storage }\end{array}$ & $\begin{array}{c}\text { Labora- } \\
\text { tory } \\
\text { storage }\end{array}$ & $\begin{array}{c}\text { Humid } \\
\text { room } \\
\text { storage }\end{array}$ & $\begin{array}{l}\text { Outdoor } \\
\text { storage }\end{array}$ & $\begin{array}{c}\text { Labora- } \\
\text { tory } \\
\text { storage }\end{array}$ & $\begin{array}{l}\text { Humid } \\
\text { room } \\
\text { storage }\end{array}$ \\
\hline $\begin{array}{l}\text { No. } 1 \\
\text { No. } 2 \\
\text { No. } 3 \\
\text { No. } 4\end{array}$ & $\begin{array}{l}12 \\
12 \\
36 \\
36\end{array}$ & $\begin{array}{l}12 \\
12 \\
36 \\
36\end{array}$ & $\begin{array}{l}12 \\
12 \\
36 \\
36\end{array}$ & \begin{tabular}{|r} 
Lbs./in..$^{2}$ \\
19.3 \\
51.8 \\
34.0 \\
21.6
\end{tabular} & $\begin{array}{r}\text { Lbs./in. }{ }^{2} \\
21.1 \\
32.7 \\
16.3 \\
5.6\end{array}$ & $\begin{array}{r}\text { Lbs./in. }{ }^{2} \\
25.3 \\
29.0 \\
39.4 \\
28.0\end{array}$ \\
\hline A verage... & & D. & .... & 31.7 & 18.9 & 30.4 \\
\hline
\end{tabular}


It does not seem that a strong bond is of necessity a durable one. This is brought out by a comparison of the values in Tablo 9 with those of Table 6 in which durability was considered. The average percentage failures of bond among units stored for two months (Table 6) under these same three conditions, and prior to testing, were (averaging brick 1 to 4, inclusire, only) 81 per cent for outdoor, 80 per cent for laboratory and $\$ 6$ per cent for humid room storage. It is believed that the stresses induced by freezing and thawing were of such magnitude that the bond failed regardless of strength.

\section{(b) STRENGTH OF BOND AS RELATED TO BRICK}

It is usually considered, and it may bo true all other things being equal, that a porous brick should be preferred to a more impervious one from the standpoint of bonding with mortar. However, it is reasonable to suppose the degree of roughness of surface to be also a factor of importance. For example, mortar has been known to adhere tenaciously to roughened glass. Brick Nos. 1 and 2 were relatively porous and smooth whereas Nos. 3 and 4 were relatively impervious and rough surfaced. Table 10 gives a direct comparison between these different makes of brick with respect to bonding qualities. These are averages for all conditions of storage and with $1: 1: 6$ mortar. The individual maximum values were obtained with units stored in the humid room and the minimum values with units stored in the laboratory.

TARte 10.-Strength of bond with different makes of brick $(1: 1: 6$ mortar, with and without lugs)

\begin{tabular}{|c|c|c|c|c|c|c|}
\hline - & Brick & $\begin{array}{l}\text { A rerage } \\
\text { bond } \\
\text { strength }\end{array}$ & $\begin{array}{l}\text { Number } \\
\text { aver- } \\
\text { aged }\end{array}$ & $\begin{array}{l}\text { Indi- } \\
\text { vidual } \\
\text { maxi- } \\
\text { mum }\end{array}$ & $\begin{array}{l}\text { Indi- } \\
\text { vidual } \\
\text { mini- } \\
\text { muw }\end{array}$ & $\begin{array}{l}\text { Percent- } \\
\text { age of all } \\
\text { units ex- } \\
\text { ceeding } \\
\text { in bond } \\
\text { strength } \\
30 \\
\text { Lbs./in.? }\end{array}$ \\
\hline $\begin{array}{l}\text { No. } 1 \\
\text { No. } 2 \ldots\end{array}$ & & $\begin{array}{r}\text { I.bs./in. }{ }^{2} \\
21.9 \\
37.8\end{array}$ & $\begin{array}{l}36 \\
36\end{array}$ & $\begin{array}{r}\text { Lbs./in. }{ }^{2} \\
62.3 \\
\quad 11.5\end{array}$ & $\begin{array}{r}\text { Lbs./in.2 } \\
0.5 \\
1.2\end{array}$ & $\begin{array}{l}4 i .2 \\
72.2\end{array}$ \\
\hline A rerage... & & 29.9 & - . n n & ....... & ..... & . \\
\hline $\begin{array}{l}\text { No. } 3 \ldots . . . \\
\text { No. } 4 \ldots . .\end{array}$ & & $\begin{array}{l}29.9 \\
15.4\end{array}$ & $\begin{array}{l}10 \mathrm{~s} \\
10 \mathrm{~s}\end{array}$ & $\begin{array}{l}53.5 \\
63.9\end{array}$ & 1. 3 & $\begin{array}{l}23.7 \\
52.5\end{array}$ \\
\hline Average. & & 24.2 & & & & \\
\hline
\end{tabular}

The averages indieate some improvement in strength of bond through the use of porous brick. However, the difference is not marked. The individual maximum values and the percentages (Table 10) certainly indicate that it is possible to bond satisfactorily a dense, relatively impervious brick. In the case of the individual maxima the tensile strength of the mortar rather than the degree of adhesion of it to brick was measured for, after breaking, practically as much mortar adhered to one brick as adhered to the other. In the ease of the minimum values, obtained with units stored in the laboratory, this was not the case. Here the top brick broke "clean" from the mortar. 


\section{(c) STRENGTH OF BOND VERSUS ABSORPTION OF BRICK}

In considering brick molded by the same process and from the same clay or shale, are the relatively more porous brick bonded more strongly? It may seem that this question has already been considered in Table 10. However, in that case different makes of brick were considered. In Table 11 averages similar to those of Table 5 are given and show no significant difference.

ТАBLE 11.-Effect of apparent porosity of brick on slrength of bond (1:1:6 morlar, with and without lugss)

\begin{tabular}{|c|c|c|c|c|c|c|}
\hline \multirow{2}{*}{ Brick } & \multicolumn{3}{|c|}{$\begin{array}{l}\text { Units formed with brick of } \\
\text { groups } 1 \text { to } 3 \text {, fnclusive, lower } \\
\text { range of absorption }\end{array}$} & \multicolumn{3}{|c|}{$\begin{array}{l}\text { Units formed with brick of } \\
\text { kroups } 4 \text { to } 6 \text {, inclusive, high } \\
\text { range of absorstion }\end{array}$} \\
\hline & $\begin{array}{l}\text { Absorp- } \\
\text { tion } \\
\text { range }\end{array}$ & $\begin{array}{l}\text { Strength } \\
\text { of hond, } \\
\text { average }\end{array}$ & $\begin{array}{l}\text { Number } \\
\text { aver- } \\
\text { aged }\end{array}$ & $\begin{array}{l}\text { Absorp- } \\
\text { tion } \\
\text { range }\end{array}$ & $\begin{array}{l}\text { Strength } \\
\text { of bond, } \\
\text { average }\end{array}$ & $\begin{array}{l}\text { Number } \\
\text { aver- } \\
\text { agerd }\end{array}$ \\
\hline $\begin{array}{l}\text { No. } 1 \\
\text { No. } 2 . \\
\text { No. } 3 \\
\text { No. } 1 .\end{array}$ & $\begin{array}{l}\text { Pet cent } \\
9.5-12.5 \\
11.5-14.5 \\
4.8-7.0 \\
5.2-8.0\end{array}$ & $\begin{array}{r}\text { Lbs./in. }{ }^{2} \\
23.7 \\
36.8 \\
36.3 \\
19.5\end{array}$ & $\begin{array}{l}18 \\
18 \\
54 \\
54\end{array}$ & $\begin{array}{l}\text { Per cent } \\
\text { 32. 5-15.5 } \\
14.5-17.5 \\
7.0-0.8 \\
8.0-10.7\end{array}$ & $\begin{array}{r}\text { Lhs./in. } \\
20.9 \\
38.8 \\
23.5 \\
17.0\end{array}$ & $\begin{array}{l}18 \\
18 \\
54 \\
54\end{array}$ \\
\hline Average. & & 29.1 & & & 25.0 & \\
\hline
\end{tabular}

(d) STRENGTH OF BOND AS RELATED TO DEGREE OF WETTING BRICK

Although data obtained with units of brick 1 and 2 , set dry and 50 per cent saturated, are not included in the averages given in Tables 9,10 , and 11 , they have been considered. Averages, including values obtained with all conditions of saturation, are given in 'Table 12.

TABLE 12.-Effect of degree of wetting brick on strength of bond. Averages for 36 units (1:1:6 mortar, with and, withoul lugs)

\begin{tabular}{|c|c|c|c|}
\hline \multirow[b]{2}{*}{ Brick } & \multicolumn{3}{|c|}{$\Lambda$ verage } \\
\hline & $\begin{array}{l}\text { Brick } \\
\text { 80 per cent } \\
\text { saburated }\end{array}$ & $\begin{array}{c}\text { Brick } \\
50 \text { per cent } \\
\text { saturated }\end{array}$ & $\begin{array}{l}\text { Brick } \\
\text { got dry }\end{array}$ \\
\hline $\begin{array}{l}\text { No. } 1 \\
\text { No. } 2 \\
\text { No. } 3 \\
\text { No. } 4\end{array}$ & $\begin{array}{r}\text { Lbs./in.2 } \\
21.9 \\
37.8 \\
25.8 \\
20.1\end{array}$ & $\begin{array}{r}\text { Lbs./in.2 } \\
9.6 \\
16.0 \\
29.1 \\
17.1\end{array}$ & $\begin{array}{r}\text { L68. in. }{ }^{2} \\
6.8 \\
0.5 \\
35.0 \\
18.0\end{array}$ \\
\hline
\end{tabular}

Figure 7 illustrates the effect of not wetting sufficiently a rapidly absorbing brick at the time of laying it in a wall. In this case, tho two individual brick of type No. 1 were 50 per cent saturated when the unit was formed. Note the unbonded areas. In this connection one should realize that it is the rate rather than the amount of ahsorption that must be given most consideration. A rapidly absorbing brick tends to dry the wet mortar very quickly when it is first applied. When so quickly dried, the mortar loses plasticity and does not make intimate contact with the entire surface as it should. At the same time a brick when laid should not be so thoroughly saturated that it can absorb no water. A little suction is necessary to form the best 
bond. It is difficult to draw anr definite line even for one particular make of brick; however each brick manufacturer should study his material and be able to make recommendations to the user as to the proper degree of wetting his brick.

\section{(e) EFFECT OF METAL LUGS}

In Table 13 are given results which may indicate the effect of restraining any morement of the brick in a direction perpendicular to the plane of the mortar bed. As already described, this was accomplished by embedding brass lugs in the mortar. The possible reasons for these differences have already been discussed in connection with the data of Table 4 which tend to corroborate those in Table 13.

TABLE 13.-Efict of lugs on bond strength $(1: 1: 6$ mortar)

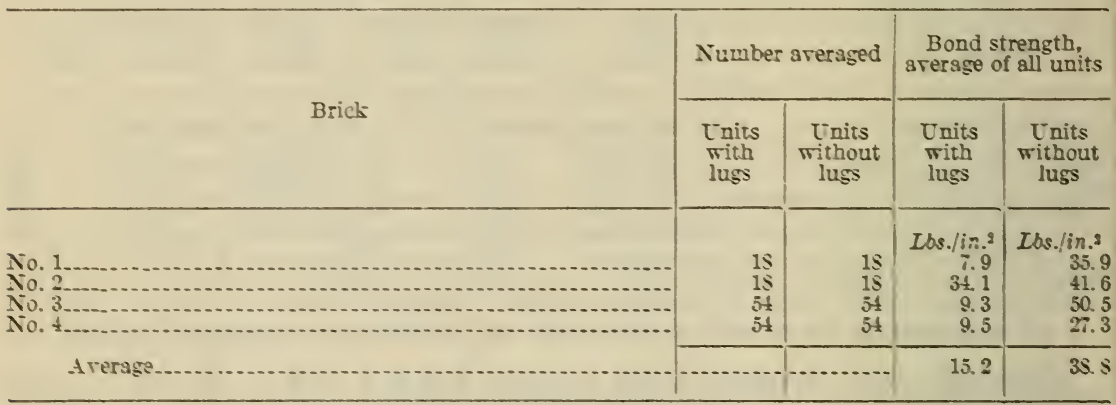

(f) STRENGTH OF BOND IN UNITS SURVIVING FREEZING AND THAWING TESTS

As stated previously, the units that survived the freezing and thawing tests were also tested for strength of bond. The results are given in Table 14. These averages include all units not loaded, made with $1: 1: 6$ mortar, and stored under all three conditions for two months prior to undergoing the freezing and thawing tests.

TABLE 14.-Strength of bond in units surviving freczing and thawing tests $(1: 1: 6$ moriar, with and without lugs)

\begin{tabular}{|c|c|c|}
\hline Srick & $\begin{array}{l}\text { Yumber } \\
\text { of units } \\
\text { tested }\end{array}$ & $\begin{array}{l}\text { A rersge } \\
\text { strength } \\
\text { of bond }\end{array}$ \\
\hline $\begin{array}{l}\text { No. } 1 \\
\text { No. } 2 \\
\text { No. } 3 \text { No. } \\
\text { No. } 5\end{array}$ & $\begin{array}{r}12 \\
3 \\
20 \\
5 \\
21\end{array}$ & $\begin{array}{c}\text { Lbs.in.: } \\
45.1 \\
21.6 \\
29.1 \\
23.0 \\
22.7\end{array}$ \\
\hline
\end{tabular}

The arerage strength of bond for those units made with brick Nos. 1 to 4 , inclusire, which survired the freezing and thawing tests compares farorably with similar data for the same brick, but for units not subjected to freezing and thawing as given in Table 10 . Since all of the units formed with brick No. 5 were subjected to freezing and thawing tests, data of the kind given in Table 10 were not obtained for this brick.

This comparison shows beyond a doubt that the bond failure was not due to disintegration of mortar. Had such been the case, the 
average values in Table 14 would be less than the averages given in Table 10. This was also evident from visual inspection. There was no visible disintegration, chipping, or spalling of either brick or mortar during these tests.

(g) STRENGTH OF BOND AS RELATED TO MORTAR

Table 15 presents a summary of the results obtained with all of the survivors of all of the units made from brick No. 5 .

TABLE 15.- Strength of bond as related to mortar used (units loaded and not loaded, with and without lugs)

\begin{tabular}{|c|c|c|c|c|c|c|c|c|c|c|}
\hline \multirow{3}{*}{ Mortar } & \multicolumn{5}{|c|}{ Units loaded } & \multicolumn{5}{|c|}{ Units not loaded } \\
\hline & \multirow{2}{*}{$\begin{array}{l}\text { Total } \\
\text { num- } \\
\text { ber of } \\
\text { units } \\
\text { made }\end{array}$} & \multirow{2}{*}{$\begin{array}{l}\text { Num- } \\
\text { ber of } \\
\text { surviv- } \\
\text { ors test- } \\
\text { ed for } \\
\text { strength }\end{array}$} & \multicolumn{3}{|c|}{ Strength } & \multirow[b]{2}{*}{$\begin{array}{l}\text { Total } \\
\text { num- } \\
\text { ber of } \\
\text { units } \\
\text { made }\end{array}$} & \multirow{2}{*}{$\begin{array}{l}\text { Num- } \\
\text { ber of } \\
\text { surviv- } \\
\text { ors test- } \\
\text { ed for } \\
\text { strength }\end{array}$} & \multicolumn{3}{|c|}{ Strength } \\
\hline & & & $\begin{array}{l}\text { Aver- } \\
\text { age }\end{array}$ & $\begin{array}{l}\text { Indi- } \\
\text { vidual } \\
\text { maxi- } \\
\text { mum }\end{array}$ & $\begin{array}{l}\text { Indi- } \\
\text { divual } \\
\text { mini- } \\
\text { mum }\end{array}$ & & & $\begin{array}{c}\text { Aver- } \\
\text { age }\end{array}$ & $\begin{array}{l}\text { Indi- } \\
\text { vidual } \\
\text { maxi- } \\
\text { mum }\end{array}$ & $\begin{array}{l}\text { Indi- } \\
\text { vidual } \\
\text { mini- } \\
\text { mum }\end{array}$ \\
\hline $1: 3-\ldots$ & $\begin{array}{l}108 \\
108\end{array}$ & $\begin{array}{l}76 \\
63\end{array}$ & $\begin{array}{c}\text { Lbs./- } \\
\text { in. }{ }^{2} \\
27.3 \\
15.5\end{array}$ & $\begin{array}{c}\text { Lbs./- } \\
\text { in.2 } \\
84.0 \\
71.6\end{array}$ & $\begin{array}{r}L b s . /- \\
\text { in.2 } \\
1.9 \\
2.0\end{array}$ & $\begin{array}{l}108 \\
108\end{array}$ & $\begin{array}{l}37 \\
21\end{array}$ & $\begin{array}{c}\text { Lbs./- } \\
\text { in.2 } \\
31.3 \\
22.7\end{array}$ & $\begin{array}{c}\text { Lbs./- } \\
\text { in.2 } \\
69.9 \\
60.9\end{array}$ & $\begin{array}{l}\text { Lbs./- } \\
\text { in. } \\
5.4 \\
7.4\end{array}$ \\
\hline
\end{tabular}

The data indicate that the strength of bond in units which survived the 50 freezing and thawing cycles was not measureably improved by loading.

With reference to the units described in Table 15 it may be mentioned that, when those bonded with $1: 3$ cement-sand mortar were pulled apart, but very little mortar remained on the top brick in practically all cases. The fracture was largely one of bond failure, occurring at the junction of the mortar and the upper brick. This was true regardless of whether or not the units had been loaded. However, in the case of $1: 1: 6$ mortar units which were loaded, this was not the case. After the brick in these loaded units were pulled apart, as much mortar was adhering to the upper as to the lower brick in most cases; actually, it was the tensile strength of the mortar rather than the strength of bond that was measured. Among units not loaded and made with 1:1:6 mortar, the mortar usually adhered more or less over the entire surface of the upper brick, but was less in amount than that clinging to the lower brick. This last statement applies also to units made from brick 1 to 4 , inclusive, and to both those units which were and those which were not subjected to freezing and thawing. This means briefly that the ratio, strength of bond to tensile strength of mortar, was greater in 1:1:6 than in $1: 3$ mortar.

\section{CONCLUSIONS}

1. The above data indicate that failure of bond between mortar and brick, under the conditions described, was not due to disintegration of either brick or mortar.

2. Dense impervious brick which absorb water very slowly can be bonded satisfactorily with mortar. 
3. Under the same or nearly the same conditions, the strength of bond attained by using relatively porous brick tended to be slightly greater than that characteristic of units formed with relatively impervious brick. However, in so far as durability of bond (as determined in the manner described) is concerned, the absorption properties of the brick were not of any considerable importance when due regard was given to the necessity of thoroughly wetting the rapidly absorbing brick.

4. With good workmanship, there were other considerations which in their effect on the bond durability were of more importance than the absorption properties of the brick. These were: The amount of pressure which the mortar bed sustained during the tests, whether or not the brick were free to move so as to tend to reduce stresses induced by shrinkage in the mortar; and the type of mortar that was used.

5. There was nothing to be gained either from the standpoint of strength or of durability of bond by wetting brick which did not wet through from edge to edge within less than 4 hours time.

6 . The ratio, strength of bond to tensile strength, was greater in $1: 1: 6$ than in $1: 3$ mortar.

7. There was a slightly greater percentage of failures of bond with the $1: 1: 6$ than with the $1: 3$ mortar.

8. The percentage failures of the nonloaded units was twice that of the loaded ones. This may be interpreted as indicating that bond failure is most likely to occur in vertical joints in masonry. It would be well to have an absolute minimum of such joints and to adequately protect them from moisture as much as possible in order to avoid excessive water penetration through cracks formed between the masonry units and the cementing material.

9. There were appreciably more bond failures when metal lugs were embedded in the mortar joints than there were when such were omitted. It was intended in this procedure to simulate in one-half of the units, conditions whereby the brick could not be drawn nearer together as the mortar shrunk. Such a condition apparently exists sometimes in vertical joints in masonry.

10. These data suggest the necessity of continuing studies of all types of masonry materials and broadening their scope in order that, ultimately, mortar and building units generally may be better adapted to one another and that the life of the bond in exposed places in all masonry construction may be materially increased.

\section{ACKNOWLEDGMENTS}

The authors wish to extend their thanks to Messrs. Bates, Parsons, and Mitchell, of the staff of the National Bureau of Standards, for their helpful suggestions given during the course of this investigation. Grateful acknowledgment is also made of the cooperation of members of the research committee and of the secretary and president of the American Face Brick Association.

Washington, January 9, 1931. 